\title{
Hasil Temuan Suspect BTA Sebelum dan Sesudah Program Ketuk Pintu oleh Kader Berdasarkan Kualitas Sampel Dahak
}

\section{BTA Suspect Findings Before and After Knocking on the Doors Program by Cadre Based on Quality of Sputum Samples}

\section{DEDE SUMIATI TEGUH BUDIHARDJO}

\author{
Jurusan Analis Kesehatan Poltekkes Kemenkes Semarang \\ Jl. Wolter Monginsidi Pedurungan Tengah Semarang \\ E-mail:teguhbudi41@yahoo.com
}

\begin{abstract}
Abstrak
Tujuan Penelitian ini adalah untuk mengetahui perbedaan hasil temuan suspect BTA sebelum dan sesudah program ketuk pintu oleh kader Tahun 2017 berdasarkan kualitas sampel dahak di wilayah UPTD Puskesmas Kroya II.Jenis penelitian yang dilakukan adalah deskriptif kuantitatif. Analisa data menggunakan uji beda Independent t-test (bivariat) dengan bantuan SPSS 24. Hasil penelitian menunjukan jumlah suspect TB sebanyak 226 orang dengan temuan BTA + sebelum program ketuk pintu oleh kader sebanyak 29,2\%, sesudah program jumlah suspect sebanyak 367 orang dengan temuan BTA + sebanyak 3,3\%. Ini menunjukan bahwa terdapat perbedaan hasil temuan suspect BTA sebelum dan sesudah program ketuk pintu oleh kader tahun 2017 berdasarkan kualitas sampel dahak di wilayah UPTD Puskesmas Kroya II.
\end{abstract}

Kata Kunci: BTA ; Suspect ; Program Ketuk Pintu

\begin{abstract}
The purpose of this study was to determine the difference between the findings of BTA suspect before and after the door knock program by cadres in 2017 based on the quality of sputum samples in the UPTD Kroya II Community Health Center. The type of research conducted was quantitative descriptive. Data analysis used a different test of Independent t-test (bivariate) with the help of SPSS 24. The results showed 226 suspect numbers of TB with BTA + findings before the program knocked on the door by cadres as much as $29.2 \%$, after the program the number of suspects was 367 people with BTA + findings were $3.3 \%$. This shows that there are differences in the findings of BTA suspect before and after the door knock program by cadres in 2017 based on the quality of sputum samples in the UPTD Kroya II Health Center.
\end{abstract}

Keyword: BTA ; Suspect ; Program Tap the Door

\section{Pendahuluan}

Tuberkulosis (TB) merupakan penyakit menular yang disebabkan oleh infeksi kuman Mycrobacterium tuberculosis. Tuberkulosis dapat menyebar melalui droplet orang yang telah terinfeksi basil TB. Tuberkulosis bersama dengan malaria dan HIV/AIDS, tuberkulosis menjadi salah satu penyakit yang pengendaliannya menjadi komitmen global dalam Millenium Development Goals (MDG's) (Kemenkes RI, 2011).

Indonesia merupakan negara dengan penyumbang kasus Tuberkulosis (TB) paru terbanyak kedua di dunia setelah India. Akumulasi kasus di India, Indonesia dan Cina sendiri menyumbang 46\% kasus dari semua total kasus TB paru di dunia, TB di Indonesia juga merupakan penyebab kematian menempati urutan ke empat setelah penyakit kardiovaskuler, 
diperkirakan setiap empat menit sekali satu orang meninggal akibat TB di Indonesia. (WHO, 2015).

Prevalensi TB di Jawa Tengah sebesar 28 per 100.000 penduduk,, Kabupaten Cilacap menempati urutan ke 15 untuk kasus TB di Provinsi Jawa Tengan dengan prevalensi 22 kasus per 100.000 penduduk (Dinkes Jateng, 2016). Sedangkan di Wilayah kerja UPTD Puskesmas Kroya II prevalensi TB pada tahun 2017 sebanyak 0,8\% (Dinkes Cilacap, 2017).

Menurut Depkes RI (2008), penatalaksanaan penanggulangan TB Paru dimulai dari :

Penemuan penderita Tuberkulosis Paru secara pasif, artinya penjaringan tersangka penderita dilaksanakan pada mereka yang datang berkunjung ke unit pelayanan kesehatan terutama dengan keluhan dahak bercampur darah, batuk darah, sesak nafas dan rasa nyeri dada maka penderita tersebut sudah harus dicurigai atau dianggap sebagai seorang "suspek tuberculosis" atau tersangka Tuberkulosis Paru dan perlu dilakukan pemeriksaan dahak secara mikroskopis langsung.

Salah satu cara dalam meningkatkan temuan suspek kasus TB yaitu dengan metode ketuk pintu oleh kader atau yang disebut dengan Gerakan Ketuk Pintu Toss TB, dimana dalam program tersebut melibatkan kader untuk mengumpulkan sputum orang yang diduga menderita TB (Kemenkes, 2016). Dengan adanya program Ketuk Pintu tersebut diharapkan dapat meningkatkan jangkauan dalam mendapatkan suspect TB baru.

Diagnosis TB paru pada dewasa dapat ditegakkan dengan ditemukan bakteri tahan asam (BTA) pada pemeriksaan dahak/sputum penderita secara mikroskopis (Adelberg et all, 2008). Sputum (dahak) adalah bahan yang dikeluarkan dari paru dan trakea melalui mulut. Biasanya juga disebut dengan ecpectoratorian (Dorland, 2009). Sputum, dahak, atau riak dalam hal ini adalah sekret yang dibatukkan dan berasal dari tenggorokan, hidung atau mulut.

Sputum yang baik mengandung beberapa partikel atau sedikit kental dan berlendir,kadang kadang bernanah dan berwarna hijau kekuningan.(Bastian,Ivan dan Lumb,2008). Sputum dapat dibedakan dengan ludah antara lain: ludah biasa akan membentuk gelembung-gelembung jernih di bagian atas permukaan cairan, sedang pada sputum hal ini jarang terjadi. Secara mikroskopis ludah akan menunjukan gambaran sel-sel gepeng sedang pada sputum hal ini tidak ditemukan. Sputum paling baik untuk pemeriksaan adalah sputum pagi hari, karena sputum pagi paling banyak mengandung kuman. Sputum pagi dikumpulkan sebelum menggosok gigi, tetapi sudah berkumur dengan air untuk membersihkan sisa makanan dalam mulut yang tertinggal.

UPTD Puskesmas Kroya II merupakan Puskesmas di wilayah Kecamatan Kroya dengan luas $28 \mathrm{Km}$,terdiri dari 6 wilayah kerja, yaitu Desa Gentasari, Desa Sikampuh, Desa Mujur, Desa Mujur Lor, Desa Kedawung, dan Desa Buntu. Secara umum kondisi topografi wilayah UPTD berupa lahan persawahan dan tidak ada dataran tinggi.Sarana kesehatan yang terdapat di Wilayah UPTD Puskesmas Kroya II meliputi 2 klinik rawat inap, 2 Puskesmas Pembantu, 6 Polindes, dan 48 Posyandu.

Berdasarkan data di Laboratorium UPTD Puskesmas Kroya II pada tahun 2016 terdapat 226 sampel suspek TB, namun setelah ada program Ketuk Pintu Tahun 2017 jumlah suspek meningkat menjadi 367 orang. Hal ini yang dijadikan sebagai latar belakang peneliti untuk melakukan penelitian apakah terdapat perbedaan temuan BTA + pada program pemerintah tersebut.

\section{Metode}

Metode yang digunakan adalah kuantitatif dengan desain cross sectional retrospektif yang bertujuan untuk mengidentifikasi adanya perbedaan penemuan BTA sebelum dan sesudah program ketuk pintu oleh kader TB. Populasi dalam penelitian ini adalah seluruh orang yang menderita TBC di Wilayah UPTD Puskesmas Kroya II Kabupaten Cilacap. Pengolahan dan analisis data yang dipakai adalah Statistical Package for the Social Sciences (SPSS) versi 24,0. Uji kenormalan menggunakan kolmogorof smirnof, apabila data terdistribusi normal maka uji perbedaan menggunakan independent $t$-test (Bivariat). 


\section{Hasil dan Pembahasan}

Berdasarkan Responden pengambilan sampel dahak diambil berdasarkan kategori umur $<$ 11-65 tahun. Pada tahun 2016 dan 2017, responden rata-rata pada kelompok umur 56-65 tahun. Hal ini berarti tidak ada perbedaan yang besar terhadap umur responden dalam penelitian ini.

Kualitas dahak yang baik mengandung beberapa partikel atau sedikit kental dan berlendir, kadang-kadang malah bernanah dan berwarna hijau kekuningan. Hasil pemeriksaan dahak BTA + pada tahun 2016 sebanyak 29,2\% dan pada tahun 2017 sebanyak $3,3 \%$.

Kualitas dahak tahun 2016 paling banyak adalah nanah/lendir yaitu sebanyak 57,52\%, sedangkan tahun 2017 paling banyak adalah air liur sebesar 69,48\%. Pada tahun 2016, sampel dahak yang digunakan sebelum program ketuk pintu adalah dahak yang diperoleh dari pasien yang datang sendiri ke laboratorium. Pasien tersebut sebelumnya telah memperoleh penjelasan untuk tehnik pengambilan sampel yang benar oleh petugas TB dan petugas laboratorium, sehingga di dapat kualitas sampel yang baik dan layak untuk dilakukan pemeriksaan. Seperti dahak berbentuk porulen, mukoid (sedikit kental) dan berwarna hijau kekuningan. Adapun sampel dahak yang digunakan pada program ketuk pintu tahun 2017 memiliki kualitas sampel dahak yang kurang memenuhi syarat, berupa air liur sehingga hasil pemeriksaan menunjukkan kualitas sampel dahak yang kurang baik. Hal ini dikarenakan kader hanya melakukan pengumpulan sampel dahak untuk langsung dikirim ke laboratorium tanpa mengecek terlebih dahulu kualitas sampel dahak. Selain itu, pemahaman kader masih kurang mengenai kualitas sampel dahak yang baik.

Hasil analisa bivariat memiliki nilai Sig. (2-tailed) sebesar 0,006, nilai ini lebih rendah dari nilai $\alpha$ sebesar 0,05 . Hal ini berarti terdapatperbedaan antara hasil pemeriksaan dahak pagi pada tahun 2016 dengan hasil pemeriksaan dahak pagi pada tahun 2017. Hasil pemeriksaan dahak BTA + pada tahun 2016 sebanyak 29,2\% dan pada tahun 2017 sebanyak $3,3 \%$.

Hal ini dapat dipahami karena masih kurangnya pengetahuan dan keterampilan kader dalam mengenali ciri-ciri dan gejala-gejala penyakit TB, sehingga suspek yang dikumpulkan masih belum memenuhi syarat terkena penyakit TB.

Hasil pemeriksaan BTA + sebelum ada program ketuk pintu lebih banyak hal ini karena yang mengambil sampel adalah petugas kesehatan yang sudah mengetahui ciri-ciri penderita TB. Sedangkan pada program ketuk pintu tahun 2017 jumlah sampel memang lebih banyak, akan tetapi penemuan BTA (+) lebih sedikit karena kualitas sampel dahak yang dikumpulkan kader masih belum memenuhi syarat, kualitas sampel yang baik akan ikut menentukan hasil pemeriksaan Mikroskopis BTA.

\section{Simpulan dan Saran}

\section{Simpulan}

Pada tahun 2017 jumlah suspect TB setelah program ketuk pintu oleh kader jauh lebih banyak, akan tetapi temuan BTA + jauh lebih sedikit dari tahun 2016. Pada program tersebut, ditemukan juga kualitas sampel dahak yang belum memenuhi syarat. Oleh karena itu, hasil tes bivariat terdapat perbedaan hasil temuan suspect BTA sebelum dan sesudah program ketuk pintu oleh kader tahun 2017 berdasarkan kualitas sampel dahak di wilayah UPTD Puskesmas Kroya II.

\section{Saran}

Program ketuk pintu oleh kader sebaiknya dilanjutkan untuk tahun berikutnya karena meningkatkan jumlah suspek TB yang diperiksa. Kader kesehatan sebaiknya diberikan pelatihan tentang informasi penyakit TB sehingga meningkatan pengetahuan dan keterampilan dalam mengenali gejala-gejala penyakit TB dan dapat mengenali kualitas sampel dahak yang baik. 


\section{Daftar Pustaka}

Alfath, Adelberg et all. 2008. Mikrobiologi Kedokteran (terj.). Jakarta : Buku Kedokteran EGC Halaman 627-629.

Depkes - IDAI. 2008. Diagnosis dan Tatalaksana Tuberkulosis pada Anak. Kelompok Kerja TB Anak. Jakarta.

Depkes. RI. 2008. Pedoman Nasional Penanggulangan Tuberkulosis. Jakarta.

Dinkes Cilacap. 2017. Profil Kesehatan Provinsi Kabupaten Cilacap Tahun 2017. Cilacap.

Dinkes Jawa Tengah. 2016. Profil Kesehatan Provinsi Jawa Tengah Tahun 2016. Semarang.

Dorland. 2009. Kamus Kedokteran Dorland. Jakarta : Buku Kedokteran EGC.

IDAI, 2008. Diagnosis dan Tatalaksana Tuberkulosis Anak. Jakarta : Departemen Kesehatan Republik Indonesia.

Jawetz, et al. 2008. Mikobakterium. Dalam: Brooks GF, Butel JS, Morse SA, penyunting. Mikrobiologi Kedokteran (Edisi ke-23). Jakarta : Buku Kedokteran FKUI, 2008; h.325. Kedua. Jakarta : Bakti Husada.

Kemenkes RI. 2011. Standar Antropometri Penilaian Status Gizi Anak. Jakarta : Direktorat Bina Gizi.

Sastroasmoro, S. Sofyan I. 2014. Dasar-Dasar Metodologi Penelitian Klinis Edisi ke-5. Jakarta : CV. Sagung Seto. p:130-7, 352-17.

Wahyuni, dan Eksanoto, D. 2013. Hubungan Tingkat Pendidikan dan Jenis Kelamin dengan Kejadian Hipertensi di Kelurahan Jagalan di Wilayah Kerja Puskesmas Pucang Sawit Surakarta. Jurnal Ilmu Keperawatan Indonesia. Halaman : 79-85.

World Health Organization (WHO). 2015. Global Tuberculosis Report 2015. Switzerland. 